\title{
Theorizing the Flagbody: Symbolic Dimensions of the Flag Desecration Debate, or, Why the Bill of Rights Does Not Fly in the Ballpark
}

Carolyn Marvin

University of Pennsylvania, cmarvin@asc.upenn.edu

Follow this and additional works at: https://repository.upenn.edu/asc_papers

Part of the Communication Commons

\section{Recommended Citation}

Marvin, C. (1991). Theorizing the Flagbody: Symbolic Dimensions of the Flag Desecration Debate, or, Why the Bill of Rights Does Not Fly in the Ballpark. Critical Studies in Mass Communication, 8 119-138. https:// doi.org/10.1080/15295039109366786

This paper is posted at ScholarlyCommons. https://repository.upenn.edu/asc_papers/659

For more information, please contact repository@pobox.upenn.edu. 


\title{
Theorizing the Flagbody: Symbolic Dimensions of the Flag Desecration Debate, or, Why the Bill of Rights Does Not Fly in the Ballpark
}

\begin{abstract}
This paper analyzes American flag symbolism in public debate about the Supreme Court's flagburning decisions in 1989 and 1990, and in related flag events. The connotated flag is systematically represented by champions of flag protection laws as a sacrificial body contrasted both to the bodiless text and the profane body of flagburning. What is at stake in the flagburning debate is a cultural fight between the body and the text, and a notion of the sanctifying drama of the American holy family.
\end{abstract}

\section{Disciplines}

Communication | Social and Behavioral Sciences 
Theorizing the Flagbody: Symbolic Dimensions of the Flag Desecration Debate, or, Why the Bill of Rights Does Not Fly in the Ballpark

\section{CAROLYN MARVIN}

This paper analyzes American flag symbolism in public debate about the Supreme Court's flagburning decisions in 1989 and 1990, and in related flag events. The connotated flag is systematically represented by champions of flag protection laws as a sacrificial body contrasted both to the bodiless text and the profane body of flagburning. What is at stake in the flagburning debate is a cultural fight between the body and the text, and a notion of the sanctifying drama of the American holy family.

"It's like stepping on your family to burn the flag. Who'd want to do that?" -Citizen comment, WPVI-TV News ${ }^{1}$

Summing up the political defeat of the proposed flag protection amendment in the House of Representatives by 34 votes, National Public Radio noted with interest that there had been flag hats, flag pantyhose, and flag bathing suits during five hours of debate, but no Bill of Rights bathing suits (All Things Considered, 1990). ${ }^{2}$ Nor does the Bill of Rights fly in the ballpark, observed NPR. What about this? What larger principles do such observations illuminate? What, if anything, is implied in the distinction between standards and constitutions?

NPR suggested that the flag is more "accessible" to citizens than the Bill of Rights and left it at that. Its microphones, meanwhile, wandered off to ask passersby what the Bill of Rights is, how many amendments are in it, whether anyone could name all ten, whether anyone could fill in the blanks if parts of the ten were read to them. A familiar vignette of civic ineptitude, this exercise demonstrated how uncertain a grasp of the particulars and significance of the Bill of Rights many citizens possess. By contrast, few such problems attach to the flag. Americans recognize the flag easily and offer accounts of its meaning with confidence. Despite the variety of these accounts, it is widely believed that the flag has a generally agreed-upon meaning, and that most people know what it is.

The flag is a sign. Like all signs, it makes sense within a semiotic system of differences. A condition for understanding what the flag is, therefore, is understanding what it isn't. The semiotic topography of the flag, the twists and turns of its public significance, can be mapped only by observing its use in symbolic practice-for example, in public discourse about flag desecration. On the basis of examples from this discourse and from other examples of symbolic practice with the flag, I will argue that beyond its primary denotative significance as an emblem of the United States, the connotated flag "is" an unacknowledged but potent symbol of the body, especially the sacrificial citizen body. What it is not is the text, especially the revealed text, which, in the debate examined here, "is" the Bill of Rights. If this set of equivalences is correct, a key semiotic opposition in the symbolism of the flag is embedded in the snippet of media culture with which this paper begins. It points further to an entire system of flag symbolism.

Additional contrasts in symbolic practice around the flag may be said to grow out of the opposition between the text and the flagbody, and to elaborate that opposition, and therefore the meaning of the flag, by adding new information. For the moment it is enough to designate these contrasts. Evidence for how they work will emerge in the course of the argument. The flagbody, a term that expresses the symbolic equivalence of the body and the flag, not only is not the text, but is a special kind of body sanctified by sacrifice. The identification of the flag with the sacred body gives rise to a second semiotic contrast between the body that, by virtue of its sacrifice, is symbolically exchangeable 
with the flag, and the profane body that is also defined by a relationship to the flag-namely, its inability to be symbolically exchanged with the flag. Still a third semiotic contrast elaborates the sacred flagbody that is not the text, and is not profane. This is the distinction between the waving sacred flagbody and the wrapped sacred flagbody, as different from one another as sacrifice is different from regeneration, which, it will be argued, may not be very different at all.

\section{WHEN IS A BODY NOT A TEXT? (WHEN IT FLIES IN THE BALLPARK)}

The culturally sturdy distinction between text and body precedes the historical existence of the American flag. Text and body are, in fact, ancient antagonists and antithetical poles in a dialogue that has been shaped around them for centuries (See Stock, 1983). Text is traditionally the weapon of those whose cultural power and entitlement to participation in social life derive from educational and other textualizing credentials that exempt them from expending their bodies in pursuit of social resources. Those who command the text are most entitled to preserve their bodies and shield them from physical effort and danger. The body, by contrast, is the emblem and resource of those without textual credentials, whose bodies are available to be used up by society and whose power and participation derive from whatever value their bodies have for cultural muscle-work. The most dramatic expression of this muscle-work is war. Text and body, therefore, represent competing concentrations of economic and social power, characteristically different concepts and artifacts, and distinctive logics and frameworks of value. From this perspective, the flag desecration debate is a piece of the symbolic struggle between partisans of the body and the text for the power to control resources and bodies, and so to set the terms of culture.

Using terms current in literacy theory, the flag is an artifact of oral culture. As a category for classifying messages, "oral" is most usefully conceptualized not exclusively (and traditionally) as a mode of aural information, but as a domain in which messages are transmitted through the agency of the immediately present, non-textual body in one or more modalities that both display the cultural and physical power of the body and include that display at one or more levels of signification attached to these messages. These modalities ${ }^{3}$ include vocal speech, bodily gesture, and the visual display of nonlinguistic bodily ornament, including makeup and other forms of body marking, masks, costumes, and other visually dramatic artifactual representations and extensions of the body. ${ }^{4} \mathrm{~A}$ national or tribal flag is (usually) a non-linguistic visual symbol that stands in place of the body or bodies that constitute the community. ${ }^{5}$ A flag has exactly the status of an emblem or escutcheon, a totem or other ritual object that represents the body and is symbolically invested with its powers and vulnerabilities. ${ }^{6}$

Flags are culturally contrasted to textual media, or written-language artifacts, which conceal and deny the body's existence in order to control it. Where the body (or its representation) is regarded as dramatic and performative, the text is taken to be circumspect and constative. Where the body is thought to be concrete, the text is considered abstract. Where the body is seen as particular, the text is described as universalizing. The simplicity of this oral-textual opposition begs to be complicated. I have done so elsewhere, arguing that textual communication cannot proceed at all without bodies, that textual theories need to be amended to take account of this fact, that the dialogic transaction between texts and bodies in particular cultural settings is coded for displaying social stratification, and that the dialogue between texts and bodies is socially manipulated to provide criteria for allocating honor, purity, authority, and other forms of symbolic and dispositive power (Marvin, 1990b). 
On its political surface, contemporary culture makes clear descriptive and evaluative distinctions between texts and bodies. As these distinctions relate to flagburning, champions of the flagbody, jockey with defenders of the disembodied text for cultural and political advantage. In a modern world, the text is the heavy favorite, if never the exclusive winner, in this struggle. Briefly put, texts master bodies and discipline them. Thus, children's bodies are disciplined in school by teachers who represent the authority of the text that is imposed on children, but also imparted to them in a way that allows them to discipline untextualized others in their turn. Thus, in the flag skirmish, the Congress bias chosen for the time being to place a higher value on the Bill of Rights, which signifies the cherished text, than on the flag, which signifies the cherished body.

Translated into the terms of class analysis, the class that has "won" the flag debate is the class that dictates culture to the class whose real bodies are offered to the sacrifice of the country and whose symbolic bodies are cast aside whenever the flag is burned. In the terms of this opposition, the desecration of the flag is the symbolic equivalent of the desecration of the physical bodies of the citizens signified by the flag, and by extrapolation, the collective body of the citizenry so signified. Whether the class in control of texts may ignore or permit to be demeaned symbols that are sacred to the class whose bodies are at risk-whether the sacred "body" of the flag can be desecrated by disrespectful disfiguration and metaphorical destruction-is the question at issue.

Students of political philosophy will recognize a fundamental premise of Western liberalism at work. That principle designates the individual body representing and containing the soul created in God's image, as inviolable sacred property. No body invested by God with natural rights may be coerced by any other. When it occurs, the collective body, the state, on behalf of the violated individual body, may punish coercive violation. In special circumstances, retribution may be administered by the violated individual body in question, one issue in the flag debate, therefore, is determining when a violation of the totem of the flag may be treated by a citizen as if It were a violation of his very own body.

The identification of the flag with the physical body points to important aspects of ritual practice surrounding the American flag, especially as a symbol of male blood sacrifice. The flag is everywhere associated with the initiation of men for war and in war, from the solemn presence of the flag at the recruiting center induction ceremony prior to departure for boot camp to the draping of the flag over the caskets of war dead, and the presentation of the flag as a memory object to family members, those attached by body ties of blood to the decreased. This primary association of the flag with the bloodletting ritual that keeps the community whole (1979), makes soldiers privileged stewards of the symbol. To borrow from Mary Douglas (1979), soldiers "hoard" the symbolic capital of the flag from others who have not been initiated into the bodily suffering of war and have not made, or shown their willingness to make, the heroic ultimate sacrifice of life, which the flag is a record. These non-initiates are said by initiates and their champions not to be entitled to challenge the symbolic exchange value of the flag asserted by those who, by virtue of an initiatory transformation, have become the signified to the flag's sign. Embodying what is signed by the flag, these initiates are deemed entitled to issue from themselves, by uttering it, the meaning of the sign.

As a record, the flag also possesses the attributes or an oral memory object. It is non-textual. Its design is unique. It has a circumstantially specific association with the bodies whose history and sacrifice it commemorates. A particular flag, and not another flag, becomes the memory object that flew in battle, or touched the casket of the remembered deceased. The value of such a flag may be generalized 
to all American flags, and the value ascribed to all American Flags, is the reciprocal foundation on which the value of any particular American flag is built.

The complex dialectic of culture combines and recombines texts and bodies as elements in a code that conveys a wide range of messages. In a high focused and widely engaged cultural conflict like the flag desecration debate, which refers to and brings to the surface larger social struggles in which many groups feel themselves to have a stake, the contested meanings of the flag are made salient in ritualized forms of political debate, and characterized in recurring rhetorical devices, figures of speech, and logical arguments used by supporters and opponents of flag desecration laws moving back and forth on the stage of public culture.

\section{A MEETING of BLOOD AND INK}

In the late twentieth century, the stage of public culture for symbolic debate about the flag is found not only in legislative chambers, but also and especially in mass media. Consider therefore, the text-body semiotic exhibited in two television programs about flagburning that aired during the height of the debate in 1990. Both originated from local affiliate stations in Philadelphia, with local anchors and non-celebrity "guests". In faithful observance of the conventions of media presentations of public conflict, the formats of both programs were designed to produce adversarial discussion about flagburning among parties labeled as occupying antithetical positions. All eight persons involved (two moderators and three guests on one program, one moderator and two guests on the other) were men except one who happened to be me and who happened to be invited to one program on account of controversy surrounding my own actions in burning a flag in a college free speech class shortly before the passage of the Flag Protection Act in September, 1989. (Collins, 1989; Marvin, 1990a; Ochs, 1990; Wiegand, 1989).

The first program aired on June 24, 1990, three days after the defeat of the proposed flag amendment in the House of Representatives (Issues and Answers, 1990). It featured two moderators and three panelists. The panelists were myself; David Kairys, a Temple University law school professor and civil rights attorney associated with liberal and radical causes; and Francis Rafferty, a Philadelphia city councilman known for his confrontational style. At the time of the debate, Rafferty was recently notorious for having shoved, on camera, the gay coordinator of the city's AIDS programs, to whom he was politically opposed, much to the delight of his constituency---the tough Irish neighborhoods of an area called "the pocket", one of the poorest blue-collar sections in the city, hemmed in by and under economic pressure from surrounding yuppie, black, and Italian neighborhoods.

The opening salvo of the debate went to Rafferty, who was asked, with reference to his status as an Army veteran, what flagburning "did" to him, as though his very person had been injured by seeing the flag burned and spit on, this a reference to footage introducing the program,

Moderator: Councilman Rafferty, you are an Army veteran, we just saw several American flags being burned. We even saw one man spit on the flag. What did it do to you to see that?

Rafferty: Well, you know it bothers me to see 'em burn, of course .... You know they really pick their shots where they burn a flag. I'd like to seen 'em burn a flag outside my office; I'd like to seen 'em burn a flag in South Philly; l'd like to seen 'em burn a flag in front of a gold Star mother, and let's see how far they get. 
For Rafferty, flagburning, an assault on the symbolic body, called for physical retaliation against the body of the flagburner. He chose, however, to focus on the significance of the flag to a Gold Star mother, a mother who has lost a son in combat.

"They think it's nothing", he said of flagburners, those who dishonor the artificial equivalent of the honorable body, the body which makes the ultimate sacrifice and thus becomes the sacred body. The true meaning of the flag declared, is found in what Gold Star mothers do with it:

When a Gold Star mother ... get that flag, you have to watch them. You have to watch what they do with that flag; they cradle that flag like they do a baby, and to them it's a symbol of that son, and when you burn that flag, you're taking another shot at her son, a son who she'll never see again. It's more than just a flag, it's that baby. that's what it is.

Babies are pure bodies; in our culture, the strongest of all physical, emotional and social bonds is thought to exist between mothers and children. Rafferty equated the flag not only with the body but with the most intimate body: the child, offspring of the mother's body and, by extension, her own bodily offering and sacrifice.

Asked to respond to this, David Kairys shifted the discussion from the concrete mother and her infant, equivalents of the flagbody, to a disembodied, abstract; universalized notion of expression. Flagburning was stripped of immediate and singular significance and recast as one among many more or less equivalent cases of expression which were, above all, textually equivalent. Flagburning was like, and therefore must be treated the same as, text. At issue was "a problem every society has about what to do about speech by some people that upsets other people". Going immediately textual to cement this equivalence, Kairys compared flagburning to

When the Islamic world was upset because Salman Rushdie wrote a book that really insulted their religion, we kind of looked at them and mocked them, like, why would they be upset by a book; don't they understand free speech?

Pursuing his point, Kairys offered another textual analogue in the person of Elijah Lovejoy, editor or a nineteenth-century abolitionist newspaper in Illinois in a community that favored slavery. Noting that Lovejoy published his paper in defiance of the great slave-supporting majority, Kairys compared Lovejoy's beleanguered minority status with that of the hypothetical South Philadelphia flagburner. In 1837 Lovejoy was murdered by a mob determined to end his abolitionist editorializing. Like veterans, concluded Kairys - leapfrogging from the unpopular and dishonorable flagburner to the unpopular but (retrospectively) honorable abolitionist to the popular and honorable veteran - Lovejoy was also a martyr to the flag. His body had been sacrificed for the right to textual expression of a sentiment at least as unpopular in its day as flagburning.

The moderator introduced a new example, a different sort of text. pornographic magazines, images and writing associated with the shameful and dishonorable - which is to say, profane - body. At some newsstands, he noted, pictures on the covers of such magazines are concealed (the text divorced from the picture-body) so that only the titles, or textual identities, of these magazines are visible. There are texts, was his point, that we do restrict, and they are associated with shameful and dishonorable bodies. Rafferty picked up this point. Just as the Supreme Court had ruled that shameful-body texts, or pornography, may be governed by community standards, he argued, representing these standards as bodies poised to fight over a line marked between themselves and other bodies who dared cross it, "that line finally has to be drawn" at flagburning as well. ${ }^{8}$ Rafferty's line divided his fighting--ready body from members of the intellectual/textual elite accused of countenancing flagburning-only one of a 
category of body-dishonoring body behaviors, including pornography-that violate the totem body of the community. ${ }^{9}$

The smarter we get in this country, the less respectful we get....She's a professor. As far as I'm concerned she prostituted her position as a teacher.

If to Kairys flagburning was a text, Rafferty equated flagburning, especially by a woman, with prostitution, or abuse of the body in the most morally opprobrious, that is, profane, way a woman can dishonor the body. For the textual partisan, whatever is, or is the same as, textual content can be skillfully manipulated in social battle. Divorced from the body, its effects are not physical. It can, by that token, be given free rein. The partisan of the body has a different perspective. Symbols of the body have actual force for him, and the flagburning prostitute who assaults, abuses, and profanes the totem or symbolic body ought to be subject to community punishment.

In Rafferty's view, student witnesses to my flagburning were hobbled by the need to acquire credentials in a textual world that made them uncomfortable:

She got all those kids out there. They're her kids, they're her students. There ain't too many of them going to take her on .... They're going to try and get in there and get outta there with the best marks that they possibly can.

In a world of textual power exercised by me through the medium of grades and schoolbooks, these students, dependent on me and less textually credentialed, had not been free to oppose me properly. What they should have done, however, was clear to Rafferty:

I know what I woulda done; I know what l'd 'a told my son to do, okay? Now people don't die for something, and .... Let her use a flag just because she wants to get a point?

Compared to the suffering of real bodies, the abstraction of the textual world was absurd. And I was the bad body, the whore. Rafferty addressed me directly in a way that left no doubt about my connection to the shameful body:

Why don't you burn your bra? Why don't you burn something that's close to you instead of a flag?

Pressed by the moderator to consider whether I had a right to say I wanted to burn a flag, Rafferty conceded this, but sensed a trap: "I'm not going to get into a word game with a lawyer and a professor", textual occupations both.

I'm just going to tell you emotionally how I feel about something. Now I can imagine the five of us sitting in the Academy of Music and a beautiful play is going on, an opera or something being sung, and I jump up and say, 'Asshole!' [This body-language was bleeped by the producers.] .... I'd get thrown out of there, and rightly so I'd get thrown out of there.

Rafferty's contention was that if he had uttered the name of a profane body part at an occasion culturally defined and dignified by its textual associations, its high-brow aficionados would not have hesitated to shield their pursuits from linguistic profanation and defilement. The body-language Rafferty chose for his example named a taboo bodily orifice about which nothing good could be said in Rafferty's frame of reference. For Rafferty, asshole was an unsanctifiable, shameful-body word that would never be genteel enough for association with text-identified forms such as opera and theater. This quality of honorable-body gentility, honorable partly for being decorously concealed by the text, was the criterion for expression worthy of protection in a sensible society. 
The discussion moved to the action/speech distinction. Kairys attempted to undermine Rafferty's equation of "speech" exclusively with linguistic expression, especially text, and of "action" with non-linguistic expression, or bodily behavior. In order to place flagburning and other forms of communicative "action" more securely in the category of expression, Kairys marshaled a text-conduct example from a familiar working-class context, while failing to acknowledge its obvious textual attributes. He felt sure that Rafferty

wouldn't want to ban the right to walk up and down the street with placards, to protest, whatever one wants to protest, to carry a picket sign.

As Rafferty appeared to be on the verge of protesting that this was not action at all, but speech, Kairys countered, "That's total conduct, that's not talking." He went further and cited (strategically presuming) the embarrassment of Philadelphians during the 1989 bicentennial celebration of the drafting of the Constitution, the sacred text around which this discussion pivoted, "when the police picked up a bunch of people who had signs against our involvement in Central America".

At something of a loss to manage this confusion of previously distinct categories. Rafferty regrouped by citing the frustration of those he claimed to represent and their expression of that frustration in bodily terms:

They [Kairys and Marvin] deal with different people than I do. Of course. I'm with the middle-class guy, the blue-collar guy, and I'm telling you, I hear it every day, man, 'I'm up to here, I'm up to here, I'm up to here.' And that's all you ever hear and I'm telling you something, man, we're going to make the sixties look like a picnic in the next ten years.

Pressed to elaborate, Rafferty complained bitterly that textually credentialed elites ran the country at the expense of those whose bodies were sacrificed during any war, and always cast off when their usefulness for that agenda was past:

The majority does not run this country, the minority runs this country, and that's the intellectuals, that's you professors, that's the liberal wing of this country. You run this country and you run it the way you see fit. There probably ain't fifty guys in Congress who ever served in the services left.

Observing that Congress was considering legislation to cut veterans' benefits, he concluded,

You know you're taking a shot at the very people who gave their lives for this country, their lives and limbs, and now, put 'em aside. They served. You know, when we need 'em again, we'll ... holler, 'Go get 'em, guys, anchors aweigh!' And they'll all start joining, the same kids again, and all die again, and We'll just forget about 'em again.

The discussion moved on to other things - whether debates about flagburning laws diverted the elaborate and its leaders from their real business, whether conservatism was consistent with flagburning laws, whether anything was sacred, whether citizens had enough public channels to air the diversity of their views.

Though I sought in my own remarks to avoid the body-text dichotomy, when Rafferty accused me, during a sharp exchange, of having burned the flag in pursuit of publicity, I instantly and defensively proffered a textual model as my strongest line of defense:

What I did was legal [approved in authoritative legal texts] and what I did was in defense of the Bill of Rights. I think [House majority leader] Tom Foley said it very well this week when he said all countries have flags, but only one country has a Bill of Rights. 
What is peculiar about this statement is that it reverses the direction of actual cause. It is the Bill of Rights that shields flagburning, after all, rather than the other way around. This reversal, invented in a beleaguered moment, did convey my underlying textual devotion to the Bill of Rights, and my view of it as more imperiled than the flagbody, a proposition elaborated in Tom Foley's statement that flags are multiple and fungible, while the Bill of Rights is singular.

In his closing statement, Rafferty reiterated his separation from any textual perspective, and his embrace of a body-based perspective:

I'm not going to pretend to be a philosopher or a lawyer or a student of the law, I'll just give you my gut feeling.

Throughout this exchange, Rafferty had assumed the defense of the sacred, sacrificial body at the heart of the community's identity. Kairys and I had risen to the defense of the sacred text which we placed, in our turn, at the heart of the social compact. Rafferty had fought to elevate the sacrificial body over the text that protected the interests of a more advantaged class than his constituents. And yet, because of the ability of textually skilled professionals to manipulate the public terms of the debate, he had trouble with some of the arguments and found it impossible to reject textual supremacy across the board. He himself believed the text was in some way purer than the shameful body. He argued that high-culture textual forms like opera and theater should not be defiled by profaning bodies, and could not parry the argument that carrying placards is expressive conduct, since picketing seemed to him more like the honored speech of text than the dishonorable speech of the profane body.

Confronted by a text-valuing class that displayed contempt for the body by tolerating profane flagburning (as opposed to the ritually sacred incineration of worn out or damaged flags), Rafferty defended the flagbody but accepted other invidious distinctions between texts and bodies, indeed, adopted them eagerly. He was most in a quandary over profane body-language. He argued that the epithet asshole was properly banned from polite high-culture company, company that regards textual attainment as the epitome of culture. But since, in some contexts, asshole was also valued expression among his own constituency-a fact he alluded to in one awkward exchange but apparently was reluctant to acknowledge openly in company where standards of language were prescribed by external notions of schooled text-he was uncertain of its ultimate status. (Though asshole is hardly exclusive to workingclass speakers, the social style adopted by members of textual classes may conceal this fact more successfully in public, for example, from Rafferty.) In addition, while lawyers and professors speak on television in ways that signal deference to dictionaries and other artifacts of textually disciplined language, Rafferty's language was colloquial and vernacular by comparison, and more distanced from textually standardized usage.

For Rafferty, there was the good and sacred body of the flag and the bad and profane body of prostitution, bra-burning, and inappropriate street talk in the hallowed halls of the Academy of Music. His adversaries had the advantage in this contest because their adherence to the superiority of the text over the body in virtually every case was firm. They might dismiss bad-body talk as trivial, or repudiate it as a form of bad taste, but they did not take the magic of the sacred body seriously enough to revere it especially, or fear its destruction enough to fend off attacks on it symbolized by flagburning. What they did fear were assaults on the magic of the text signified by proposals to amend the Bill of Rights. 


\section{EQUAL INVISIBILITY UNDER THE LETTER OF THE LAW}

A less confrontational exchange on a different talk show aired on Flag Day, June 14, 1990, one week before the flag amendment defeat. This program featured as principals a moderator and two guests: Alabama Sixth District Republican Congressman John Hall Buchanan, Jr., appearing on behalf of People for the American Way, a public interest group, and the commander of the Sixth District of the American Legion, Eugene Smith, a black man, both men veterans (AM Philadelphia. 1990).

Starting, as in the first program, with a direct link from body sacrifice to the flag, the moderator inquired of the American Legion commander:

I ask you, sir, as a veteran of World War II and China, India, and Burma, who got shot at and who risked your life countless numbers of times, when you see that flag burning, does that offend you personally?

Replied Smith, "Personally, it offends me because it means that the sacrifices that many like myself have gone through has gone down the drain." The moderator parried with an intellectual paradox: If we are truly free, shouldn't we be free to negate the symbols of freedom, to treat them as abstract signs, empty of intrinsic significance but open to many different, even competing, interpretations? The district commander spoke, in response, of "abusing" freedom-a term of bodily harm.

The congressman used his first turn to recall joining the Navy as a teenager. He would "never forget the first time I stood in the uniform of our country and saluted the flag", portraying for the audience in this memory his attachment to the flag through a specific bodily posture of respect. ${ }^{10} \mathrm{He}$ proceeded, all the same, to construct the familiar text-body hierarchy: "I think the way you salute, truly honor the flag, is to salute the Constitution and the Bill of Rights".

The congressman then argued for contradictory criteria, apparently without noticing, for distinguishing unacceptable violations of the text from acceptable violations of the body:

It would be unprecedented if the Congress passes an amendment weakening First Amendment protections. It has never happened in 200 years. It is unprecedented. I think it's unnecessary because once in a while somebody burns a flag as a kind of protest and it must be a very effective kind of protest, because it's caused such a hullabaloo.

Whereas a violation of rights found in and guaranteed by the text (which is to say, symbolized there, since any "guarantee" must proceed from the state's threat of violent bodies concealed behind the text) would be unacceptable on even one occasion to the congressman, occasional violation of the flagbody he considered something less-the cause of hullabaloo, which is not catastrophe-and proof, by virtue of its infrequency, of lack of threat. ${ }^{11}$ And if, at the same time, real citizen bodies ought to be inviolable (in contrast to the occasionally violable flagbody), this was only because the text itself the Constitution, is more so:

If ninety-nine percent of the people say that they're going to cut off the commander's head 'cause they don't like the look on his face, and they all agree on it, they still can't cut off his head or otherwise limit his constitutional [textually established] rights, or yours or mine. You know, this is really a philosophical issue.

The stuff and arbiter of philosophical issues, legal text and legal reasoning constrain the murderous bad-body that exercises ultimate force over another. To those like the district commander, for whom the flag signifies the body, those who "kill" the flagbody by burning it murder the community body through a similar exercise of ultimate force. 
Using a body logic much like Fran Rafferty's, Eugene Smith argued for limits on protected speech:

I can't go down to City Hall and make an obscene act at City Hall because I don't like the way the city administration is operating and not be arrested. I can't do that. Philosophically, I can be against what they're saying, but when I go and make this thing a physical thing, the moment I become violent and physical... Burning the flag is violent and physical as much as anything else.

To act against the flag is to act against a virtual body. Flagburning is therefore body-speech that is as unacceptable as obscenity or assault. "Philosophical" speech is body-distanced and abstract, the epitome of acceptable textual speech, the antithesis of obscenity, assault, and flagburning, which were non-text and non-speech in the district commander's view.

Perhaps the most interesting body issue was raised around the charge by a caller to the show that the black commander should be ashamed to oppose flagburning on a platform that the flag symbolizes the body's sacrifice for freedom. The caller argued that freedoms for working men and women had been wrested from the government, not benignly bestowed by it, and not least in the case of the district commander's own ancestors, a category that was quickly extended to the disproportionately large number of black Americans, in comparison to their numbers in the population, who served in Vietnam and sacrificed their lives.

The commander did not recognize race, as bodily an issue as there is, as having anything directly to do with flag desecration, but both the white moderator and the white congressman felt otherwise. It was this particular body issue that made flagburning acceptable to the congressman, who otherwise professed to be offended by it:

Growing up in the bad old days, and I mean bad old days, of discrimination and white supremacy and prejudice, I was really impressed through my life with the deep patriotism of the people in the black community. But I have to tell you, if I had been a young black American instead of a young white American, I might have been tempted to burn the flag in protest or worse, because my rights had been trampled and those of my people had been trampled, generation after generation, and nobody was doing anything about it in a country that was supposed to be free.

Why did this argument about the body appeal to the congressman, who was otherwise attached to textual values and arguments? In fact, the congressman's example is not an appeal to the body's importance but a denial of it. Race is fundamentally a matter or bodies, of significance ascribed to skin color and characteristic body features. To invest in the body is to assign importance to these differences. It is the text, which is to say, the law, that homogenizes bodies and makes them equal, and so conceals them. The congressman was comfortable with a body argument that promoted textual values over bodily ones, just as Kairys' textual example of Elijah Lovejoy, printer, ennobled a man who offered his body in the service of the idea that differences among persons as a matter of skin color were inferior to claims of textually defined equality.

Even the Supreme Court, as text-bearing an institution as we have, by virtue of embodying the dispositive force of the sacred texts of the Constitution and the Bill of Rights, embraced the body-text distinction in Texas v. Johnson, 491 US, 105 L Ed 2d 342, 109 S. Ct. (1989). Striking a conciliatory note in the majority decision between the body and the text, two mighty cultural protagonists, Justice Brennan wrote, "Pregnant with expressive content, the flag as readily signifies: this Nation as does the combination of letters found in 'America'" (Texas v. Johnson. 1989, p. 354). Writing for the unreconciled minority Justice Rehnquist argued that "flag burning is the equivalent of an inarticulate grunt or roar that, it seems fair to say, is most likely to be indulged in not to express any particular idea, but to 
antagonize others" Rehnquist, C. J., dissenting, Texas v. Johnson (1989, p. 2553). Justice Rehnquist thus identified flagburning with the profaning animal-body, its grunts and roars implicitly contrasted to honorable protected speech exhibiting textualizeable content, the apparent threshold trigger for "ideas".

Testifying in June, 1990, before the Senate Judiciary Committee about the wisdom of a constitutional amendment against flag descration, Prof. Henry Paul Monaghan of Columbia University declared sympathy with the Flag Protection Act (but not a constitutional amendment) on the following grounds:

For a great many Americans (myself included) the flag is a unique symbol and, as such, should be protected from physical violation. That the fundamental interest to be protected is symbolic does not render it unimportant: "We live by symbols", Justice Holmes once observed. ${ }^{12}$

While the design of the American flag is unique with respect to other national flags, language that speaks of "unique" symbols is oxymoronic in other respects. Symbols are notoriously reproducible, accretive, and plural. The configuration of visible elements that "is" the flag is no more unique than any other signifier is unique with respect to its signified. In fact, the definition of what is and is not a desecratable American flag-as-signifier abound. The characterization of the flag as symbolically singular does appeal to traditional notions in our political culture that every soul, and every body that represents and contains it, is unique and uniquely valuable. In this context Justice Holmes's proposition that life is nourished by symbols is suggestive (though not necessarily by Justice Holmes) of a more literal connection between the symbolic flag and physical life.

All culturally prominent symbols are polysemic by necessity. No claim is made here that the flag means "only" the sacred body, or "only" the body opposed to the text, either in the culture at large or in specific arguments by various parties to the discussion. Elsewhere and as a matter of political conviction, I have argued for a flexible symbolism of the flag to which all citizens may lay equal claim, and in terms of which there can be no "wrong" meanings, so long as those meanings are entertained by someone (Marvin, 1990a). ${ }^{13}$ I do claim that the debates examined here display a systematic semiotic equivalence between the flag and the sacred body that is also found in other flag practices, including non-linguistic ones. To these I will now turn. ${ }^{14}$

\section{THE PROFANE NOT-FLAGBODY}

Where words are not the focus of attention in symbolic practice with the flag (though they certainly may be present), representations of sacred and profane bodies constructed with reference to it emerge most clearly and with the greatest contrast on occasions of high public drama, such as flag burning. During the incident that became the Supreme Court's first flag burning case, Joey Johnson's accomplices added a verbal gloss that rendered the meaning of their act unmistakable by chanting, "America, the red, white and blue, we spit on you". Linguistic profanation merely seasoned the primary profaning drama of the burning flag. In one of the more dramatic flag burnings of this period, in July 1990, members of the Revolutionary Communist Youth Brigade spread an American flag on a Los Angeles sidewalk, trampled on it while chanting, "Viva La Revolution!" set fire to it, and then 
Here the body that cannot be symbolically exchanged with the flag is the defiled pig, traditional Western animal of uncleanliness and baseness of state, as Peter Stallybrass has reminded us (Stallybrass \& White, 1986). The association of the sacrificed but profane pig with flagburning stands in sharp semiotic contrast to the sacred sacrificed flagbody that it taunts, and in taunting, dishonorably mimics.

Consider two other incidents: one embedded in the ongoing theater of national sports, the other in a soap opera of local community conflict. In both, the body that cannot be symbolically exchanged with the flag appears, like the bloody pig's head of The Los Angeles flagburning, at its most profanely contaminating. In professional sports, an ongoing nationalistic drama of sublimated sacrificial fervor, the flag debate surfaced on July 24, 1990, when comedienne Roseanne Barr audibly and with apparent forethought mangled a ballpark performance of the "Star-Spangled Banner", the national anthem to the flag. She followed this up with rude, that is, profane, body gestures-grabbing her crotch and spitting-before an audience of 30,000 at a National League baseball doubleheader between the San Diego Padres and Cincinnati Reds (Sec, "Chronicle," 1990. Also, "Roseanne Strikes Out! The Whole Crazy Story of How She Turned Into a National Disgrace", 1990. Also, Georgatos, 1990). Public response was visceral. "I almost upchucked my dinner; it was like burning the flag", USA Today (Trebbe, 1990, p. 1) quoted high-culture opera star Robert Merrill, performer of the anthem for nine presidents, as saying. Earlier in the summer, athletes also were connected to the flag debate by appearing along with veterans, in public and in the press, wearing T-shirts with the slogan, "Try and burn this one "15 Wouldbe flagburners were challenged to burn the body the flag was not only identified with, but attached to physically.

Consider also "Bacchanal at the Beach," a 1990 newspaper story in the Philadelphia Inquirer detailing offenses of summer renters in the resort town of Avalon, NJ. Locals named seven particularly egregious incidents, not just "minor summertime annoyances", but transgressions they regarded as deeply offensive. Their common denominator was one or another explicitly dishonorable body behaviors of the most profane kind, with flagburning prominently featured. The incidents included:

*The party with live music so loud people 22 blocks away complained.

*The two men who climbed atop their roof in midday to urinate into a trash can on the ground below.

*The woman and five men who engaged in group sex on their far-from-secluded dock.

*The raucous middle-of-the-night games soccer, baseball, horseshoes played right outside neighbors' windows.

*The group that burned the flag on their front lawn one afternoon [italics mine].

*The man who emerged onto his deck at 4 a.m., naked, yelling to the neighbors to wake up.

*The all-night party that culminated in an alleged gang rape (Chastain, 1990)

\section{WRAPPING THE BODY IN THE FLAG}

Mark Poster has recently proposed that "the configuration of communication in any given society is an analytically autonomous realm of experience, one that is worthy of study in its own right", $(1990$, p. 8) a notion related to Baudrillard's concept of a social code that exists independently of social 
subjects. While no code exists entirely independently of social subjects who use it, code use does create a stock of symbols related to one another by explicit and implicit practices that are available to other social subjects to reproduce or modify by their own use. In an appealing metaphor, Poster asserts that communicative patterns are "wrapped" in language. I propose that bodies are frequently "wrapped" in the flag, but this is more than a suggestive metaphor. It is a well-established symbolic practice.

The claim that a primary unarticulated signifier of the flag is the citizen body is supported by a wide variety of flag-wrapping examples from fashion, sport, and the civic life of communities. The sacrificial, generally male, citizen body is not usually at issue, however. The body that is literally and publicly wrapped in the flag is often the regenerative female citizen body from which the bountiful American way of life flows. As in the case of the sacrificial male body, the gendered representation is prevailing but not exclusive. Nor does this exhaust the stock of flagbody representations.

Current representations of the female flagbody are largely commercial, despite a long civic tradition of female bodies wrapped in the flag for patriotic demonstrations (for examples, see Mastai and Mastai, 1973). The use of the national flagbody in commercial contexts was an occasion for early concerns about desecration (see, Desecration of the American Flag, 1899). Custom has now integrated flagwrapping into what passes for American folk culture, which is shopping. In any case, the flag desecration debate has been the occasion for the fashion industry to stylishly and abundantly wrap women in the flag. A \$625 hand-knitted wool "Betsy" stole by Ralph Lauren, a flag replica, draped the otherwise apparently nude body of "Twin Peaks" co-star Sherilyn Fenn on the July, 1990, cover of New York magazine (1990). During the year of the debate, flag bathing suits, shorts, tube tops, socks, bedroom slippers, sheets, scarves, and evening gowns were much in evidence. Beyond those featured on the floor of the House of Representatives, Time magazine reported that Ralph Lauren's $\$ 300$ stars-and-stripes sweater had sold out during the fall of 1989 and that three flag bathing suits were moving briskly in stores at $\$ 72$ a suit ("Oh, Say, Can You Sell?" 1990, p. 54). Bloomingdale's Winter, 1990, mail-order catalogue featured a reversible wool flag jacket, white stars on a field of navy blue on one side, red and white stripes on the other, for $\$ 279.98$. By far the most expensive flag couturier was Perry Ellis, with a $\$ 2,000$ cashmere flag stole ("Crazy for the Red, White, and Blue", 1990).

Among abundantly flag-wrapped male bodies was American golfer Payne Stew-art, photographed in the summer of 1990 winning the British Open in a New Glory flag shirt (\$57.50) advertised by Sak's Fifth Avenue in the New York Times on Flag Day, June 14 ("New glory," 1990). No less than 14,000 stars-andstripes safe-sex condoms were distributed by Old Glory Condom Corporation during its first year of existence. (" 'Old Glory' condoms raise eyebrows", 1990). Advertising slogans like "Never flown at halfmast" connected the flag-wrapped male body part thus celebrated with regeneration rather than sacrifice, the somber message of a flag flown at half-staff. In a similar way, flag-draped caskets acknowledge the unmanned (female) state of the soldier in death. For even if the most plainly regenerative body is female, the sacrificed soldier is ultimately regenerative in the cycle of eternal return. The body committed to the earth is the symbolic seed of future generations. Perhaps not coincidentally, the buried soldier is no more actually, as opposed to symbolically, regenerative, than the male organ wrapped in a condom can be actually, rather than symbolically, regenerative.

Who else is eligible for wrapping, and who is not? In its 1990 "Portraits" campaign of famous card members, American Express included a striking photograph of former Texas Congresswoman Barbara Jordan clothed, in a white blouse and black skirt and clutching a large American flag against her august, 
which is to say, maternal and asexual, person. In less mainstream media, but with a large audience nonetheless, porn movie consumers were treated in the summer of 1990 to posters for Laze, featuring porn star Victoria Paris nude from the waist up and strategically covering her nipples with small American flags.

If anyone objected, there was no press notice. By contrast, the appearance of "crucifix-andlingerie pop idol". Madonna in October, 1990, in an MTV video campaign, "Rock to Vote", wrapping a bedsheet-sized flag around herself and using it to play peekaboo with erotic lingerie and combat boots, elicited indignant protest from the Veterans of Foreign Wars (Mcfadden, 1990). Flanked by two Marinestyle male dancers, Madonna promised to give spankings for not voting, and rapped, "Dr. King, Malcom $\mathrm{X}$, Freedom of speech is as good as sex". Madonna may have been more objectionable to VFW members than Victoria Paris (and more visible, since the porn audience is relatively furtive, and marketing strategies on behalf of it more discreetly deployed) for too publicly and defiantly linking the dissonant, profane, and politically divisive message of sexual desire, as opposed to the harmonious message of community-building sacred fertility, to the flag. Nor should pressure to distance recreational, as opposed to procreationally dutiful, sex from the flag be lightly dismissed. Consider that the New York Times urged its upscale readers readying the flag for the Fourth of July to wash it by hand and "treat it like lingerie", or intimate body clothing unless it were found to be too worn or dirty, in which case it must be burned "in private" (Washing a Flag: Treat It 'Like Lingerie', 1990).

If the above examples highlight cultural moments made more salient or at least shaped by the flag desecration debate, at a more sublimely timeless level, the most impressive of all American civicnational phallic symbols, the Washington Monument, stands in the capital as a symbol of the Father of His Country, ringed since 1959 by a magic circle of American flags. ${ }^{16}$ This arrangement could be construed as a symbolic expression of union with the female body, presumably to make a nation. ${ }^{17}$ The mother of the country, as every schoolchild knows, is Betsy Ross. In the standard historical iconography of American civic religion, she is visited by George Washington, who

calls on the humble seamstress ... in her tiny home and asks her if she will make the nation's flag, to his design. And Betsy promptly brings forth--from her lap!--the flag, the nation itself (Frisch, 1989).

And so we come full circle back to the Gold Star mother, a modern-day Betsy Ross cradling the flag, her dead son, through whose sacrifice the nation is born again. Along with Betsy Ross, the Gold Star mother is emblematic of the sanctifying drama of the American holy family: mother of the country, father of the country, and holy sacrificed child.

A final story brings these threads in the symbolic fabric of the flag partially together. In Philadelphia, as this paper is written, the Republican candidate for state senator from the 4th District, Joe Rocks, has distributed a controversial campaign flier depicting Betsy Ross sewing her flag and weeping over the Democratic candidate. "It makes me want to cry," says Betsy Ross (see Lopez; 1990). Accompanying photos depict the Arlington, Va. monument to Marines raising the flag at Iwo Jima, white crosses at the graves of soldiers at Normandy, and a disorderly group of protesters torching not one, but several American flags. The Democratic candidate, Allyson Schwartz, is running on a pro-choice, gay rights platform. If Betsy Ross, mother of the flag, is an embodiment of the American holy family, reproducing the heterosexual cycle of regenerative women and sacrificial men, a candidate--who seems to threaten those nuclear boundaries would certainly make her weep. Burning 
the flag, and being pro-choice and in favor of rights for gay men and lesbians, is very much like stepping on your family.

\section{CONCLUSION}

The Bill of Rights does not fly in the ballpark because the ballpark is a world beyond texts, a world of sacrificial male bodies striving against one another, a world the flag has made, and made for the flag. In the waving flag, the sacrificial American male body is celebrated and reigns supreme. Where the flag is a wrapping for regenerative female bodies, the bountiful American way of life is on display. Both expressions are variations on a body-referenced symbolism of the flag that also finds expression in the contemporary desecration debate. An analysis of sources from the debate suggests that beyond its ostensive reference to the American nation, the flag signifies the sacrificial citizen body, and that this model of the flag appeals to defenders of flag desecration laws. Those who argue that flagburning should be legal, even if it is not in good "taste", a concession to standards of body reference, use models of textual magic to offer a contrasting view of the nation's symbolic foundations. The pattern of bodytext symbolism identifies these two symbolic complexes as culturally opposed, and suggests that an understanding of that opposition can illuminate important linguistic and non-linguistic dimensions of practices around the flag.

Carolyn Marvin is Associate Professor of Communication at the Annenberg School for Communication, University of Pennsylvania. The author thanks a most helpful group of patriots: David DeLaura, Larry Gross, Hal Fuson, Kathleen Jamieson, Nancy Morris, Amy Sarch, Judith Shapiro, Phebe Shinn, Whitney Smith, Charles Wright, and one outlander, Christopher Smith. Special thanks for crucial conceptual discussions with one who was formerly in the service of his country, David Ingle.

\section{NOTES}

${ }^{1}$ Denise James reporting (1990). The citizen was an unnamed middle-class white suburbanite in her fifties. The occasion was the announcement of the Supreme Court's decision in United States v. Eichman 110 L Ed 2d 287 (1990), the second of the Court's decisions striking down desecration laws.

${ }^{2}$ There has been at least one case of someone wearing the Bill of Rights to the beach, although not in bathing suit form. "On MacArthur State Beach in Florida, this summer, a 43-year-old woman, wearing only a copy of the Bill of Rights and a dozen pasted-on stars, was arrested for disorderly conduct" ("The Naked and the Dread," 1990, p. 60).

${ }^{3}$ Modalities, as used here, is derived from Gross (1989).

${ }^{4}$ The most serious flaw in the conventional definition of oral culture as spoken and heard is its failure to recognize the significance of co-present visual channels which may be gestural, pictorial, or both, but are never absent. Frances Yates's (1960) classic analysis of the art of memory is fully attentive to the importance of the visual in oral culture.

${ }^{5}$ Flags also function in print contexts that re-contextualize them. This re-contextualization may then reshape their meaning in oral contexts. Flags are not themselves written-language artifacts, however. 
Just before the Gulf War, according to Whitney Smith, director of the Flag Research Center in Winchester, Mass., Saddam Hussein authorized a new Iraqi flag with a handwritten Arabic slogan, "God is Great," inscribed between the stars across the middle white horizontal stripe of the familiar Iraqi flag. This text was in Saddam's own hand, the writing of his body. Another example, the blue of the blue-andwhite Israeli flag, distinct from other Middle Eastern flags in rejecting traditional pan-Arabic national colors of red, white, black, and green signifies the blue of the Jewish prayer shawl which is wrapped around the body. The Israeli flag also makes a number of other appeals to body symbolism.

${ }^{7}$ While texts can be memory objects, they are memory objects in the sense of a unique testamentary record, rather than in a dispositive sense. The distinction is discussed in Glanchy (1979).

${ }^{8}$ Historically in the United States, the line in the sand is associated with the Alamo, where its defending general, Sam Houston, drew a line in the earth across which General Santa Anna's troops should not ride.

${ }^{9}$ Elites usually are not personally accused of flagburning. This distinction belongs to punks and vandals. "A few punks yearning for attention torch it and style themselves constitutional heroes", opined the New York Times in a lead editorial, "More Glory for Old Glory," (1990). Insofar as they oppose flag desecration laws, however, elites are accused of sponsoring flagburners.

${ }^{10}$ The military salute to the flag codes a very special body relationships, which I am indebted to David Ingle for explaining. The military salute is traditionally said to be descended from the custom of knights raising their visors to show their eyes, a vulnerable part of the body, thus negating the attack signal of visor down in preparation for charging. The salute to the flag is therefore a particular alignment of the body to the flag in a posture of non-assault. Flagburning is, by contrast, an act of assault. There is more. American soldiers salute only their superiors; all military personnel must salute to the flag, but only when it is in motion. It is in motion passing by on a standard in a parade. It is in motion at dawn, but only when it is raised, and at dusk when it is lowered. It is not in motion when it covers the casket and is not saluted then. We may speculate that the moving flag signifies the living flag. This notion is reinforced by the flag that comes to life as the day does, and departs from life as the sun sets. We may also speculate that the rippling flag often favored in representations of the flag is chosen not only because it has more visual interest than a flat unmoving flag, but also because it is suggestive of a living, that is, embodied flag.

${ }^{11 "} \mathrm{I}$ predict all of the flag burners will be sitting in the Supreme Court on May 14 and they won't fill a row," Prof. Walter Dellinger of Duke University School of Law was quoted on saying in a National Law Journal article before the second Supreme Court decision (Coyle, 1990, p. 36). It is hard to imagine a correspondingly energetic hypothetical argument by constitutional scholars that, since the Supreme Court has violated the First Amendment in only one courtroom's row of seats worth of incidents, there's not much to worry about. Congressman Buchanan's argument was also used by the New York Times in a lead editorial on Flag Day, (We the People And Our Flag, 1990, June 14): "A few misguided publicity seekers set fire to one copy of [the flag] on the Capitol steps last fall to protest something or other and to get their names on a Supreme Court case." It added, "In their rush to defend the flag, [many Americans] forget the Bill of Rights." A letter to the editor of the Philadelphia Inquirer from Herbert Fisher (1990) following the Supreme Court's Eichman decision read, "How can anyone talk about the burning of the flag when a few illiterate punks are setting fire to it? The flag is strong enough to stand on its own two feet." Letter-writer Mary Lee Haw (1990) offered this observation about flagburning: "It's 
the exercise of a feeble intellect and has all the charm and social value of watching the village idiot urinating in the middle of the street." Similar examples abound.

${ }^{12}$ Statement of Henry Paul Monaghan for the Senate Judiciary Committee Concerning Proposed Constitutional Responses to the Supreme Court Decision in United States v. Eichman (1990, p. 3).

${ }^{13}$ James Carey has identified these characteristics of symbols more formally as displacement and productivity in Communication as Culture: Essays on Media and Society (1989, pp. 27-28)

${ }^{14}$ Specific mixes of body-text symbolism must be sorted out in each case. The floor debates in the House and Senate about the flag amendment offer important challenges to the analysis presented here because of their length, the number of participants, the structural character of the debates (in which there is no requirement, as in normal conversation, for the development and tacit discipline of a common meaning) and perhaps the more homogeneous social attributes of floor debates, the televised programs are "natural" cultural events, but present a simpler structure for analysis. In them, a small number of partisans engage in an effort to justify to one another in the presence of an implied public the nature of the agreements and disagreements between them, and to focus discussion at a level where participants most peg their comments to a moderator-enforced expectation (at least) of a commonly developing discourse.

${ }^{15}$ Example: Number two Philadelphia Eagles' quarterback, Jim McMahon, whose jersey number was still in doubt, wore a T-shirt to pre-season practice "featuring an American flag and the phrase 'Just try burning this one.'” ("McMahon impresses staff" 1990).

${ }^{16}$ For many years after its completion in 1888 , the monument was, at 555 feet, the highest structure in the world.

${ }^{17}$ Any interference about the sexual symbolism of the flags at the site of the Washington National Monument requires a previous conclusion about the phallic significance of the monument itself. I can offer no better source than the biographer of Robert Mills, the original architect of the Washington National Monument. He writes in connection with the Baltimore Monument to George Washington, the obelisk design of which was the direct forerunner of Mills's design for the national monument:

In trying to describe this monument I am freshly reminded to what extent Mills imbued his compositions with character, personality-even with sex. In consequence he did not plan an lonic column, which would have feminized this creation- and the subject of it. He chose that which was most virile and elementary, to uphold his statue, the Doric, that having the least complexity of detail (Gallagher, 1935, p. 105).

\section{REFERENCES}

All Things Considered. (1990, June 23). [Radio program]. Washington, D.C.: National Public Radio.

AM Philadelphia. (1990, June 14). [Television program]. Philadelphia: WPVI-TV.

Carey, J. (1989). Communication as culture: Essays on media and society. Boston: Unwin Hyman, pp. 2728.

Chastain, S. (1990, August 31). Bacchanal at the beach. Philadelphia Inquirer, pp. D1, D8. 
Chronicle. (1990, July 27). New York Times, p. B4.

Clanchy, M. (1979). From memory to written record. England, 1066-1307). Cambridge, Mass.: Harvard University Press.

Collins, H. (1989, September 15). Penn professor burns flag to make a free speech point. Philadelphia Inquirer. p. B1, B6.

Coyle, M. (1990, May 14). Rally 'round the flag? National Law Journal 12, 36.

Crazy for the red, white, and blue. (1990, July 4). [Editorial]. New York Times, p. 30.

Desecration of the American flag. Our nation's disgrace (1899). New York: American Flag Association.

Douglass, M. and Isherwood, B. (1979). The world of goods. Toward an anthropology of consumption. New York: W. W. Norton.

Efron, S. (1990, July 9). 5 Arrested after flags are burned. Los Angeles Times, pp. B1, B8.

Fisher, H. (1990, June 21). No amendment needed [Letter to the Editor]. Philadelphia Inquirer, p. A16.

Frisch, M. (1989, March). American history and the structures of collective memory: A modest exercise in empirical iconography. The Journal of American History. 75(4), 1130-1155.

Gallagher, H. M. P. (1935). Robert Mills: Architect of the Washington Monument. 1781-1855. New York: Columbia University Press.

Georgatos, D. (1990, July 27). Furor over Roscanne's singing. National Enquirer, p. 21.

Haw, M. L. (1990, June 24). Freedoms add up [Letter to the editor]. Philadelphia Inquirer, p. D6.

Issues and Answers (1990, June 24). [Television program]. Philadelphia: WPVI-TV.

Gross, L. (1989). Mode. In Erik Barnouw (Ed.), International Encyclopedia of Communications, 3 (32-36). New York and Philadelphia: Oxford University Press and The Annenberg School of Communications.

Lopez, S. (1990). A closer look at political flier. Philadelphia Inquirer.

Marvin, G. (1990a). Bad attitudes, unnatural acts Free Speech Yearbook 28, 1-7.

Marvin, C. (1990b, July). The body of the text: Literacy's corporeal constant. In S. de Castell-Jungheartz, Voice / Text / Image Education for a post-literate culture. Symposium, Simon-Fraser University, Vancouver.

Mastai, B. and Mastai, M.D. (1973). The stars and the stripes; the American flag as art and as history from the birth of the republic to the present. New York: Alfred A. Knopf.

McFadden, R.D. (1990, October 20). Wrapped in U.S. flag, Madonna raps for vote. New York Times, p. 7. McMahon impresses staff. (1990, July 27). Philadelphia Inquirer, p. C5. 
Monaghan, H. (1990, June 18). Statement for the Senate Judiciary Committee Concerning Proposed Constitutional Responses to the Supreme Court Decision in United States v. Eichman, p. 3. New York: Author.

More glory for old glory. (1990., June 12). [Lead editorial]. New York Times, p. A20.

New Glory. (1990, June 14). [Newspaper advertisement for Sak's Fifth Avenue]. New York Times, p. A4.

New York. (1990, July 2-9). [Magazine cover].

Ochs, S. (1990, March 22). State House desires prof's flag burning. Daily Pennsylvanian. pp. R4.

Oh, say, can you sell? (1990, July 9). Time. p. 54.

'Old Glory' condoms raise eyebrows. (1990, October 22). Au Courrant, p. 8.

Poster, M. (1990). The mode of information: Poststructuralism and social context. Chicago: University of Chicago Press.

Roseanne strikes out! The whole crazy story of how she turned into a national disgrace. (1990, August 14). National Enquirer, pp. 28-29, 36.

Stallybrass, P., and White, A. (1986). The politics and poetics of transgression. Ithaca, N.Y.: Cornell University Press.

Stock, B. (1983). The implications of literacy: Written language and models of interpretation in the eleventh and twelfth centuries. Princeton, N.J.: Princeton University Press.

Texas v. Gregory Lee Johnson, 491, U.S., 105 L Ed 2d 342, 109 S Ct. (1989).

The naked and the dread. (1990, September 10), Newsweek, p. 60.

Trebbe, A. (1990, July 27-29). Roseanne's shrill 'anthem' hits sour note. USA Today, p. 1.

United States v. Shawn E. Eichman 110L, Ed, 2d, 237 (1990).

Washing a flag: Treat it 'like lingerie' (1990, June 30). New York Times. p. 30.

We the people. And our flag. (1990, June 14). [Lead editorial]. New York Times. p. A26.

Wiegand, G. (1989, September 16). Penn backs teacher who burned flag. Philadelphia Inquirer, pp. B1, B3.

Yates, F. (1960). The art of memory. Chicago: University of Chicago. 